\title{
Political ridicule and humour under socialism
}

\author{
Christie Davies
}

University of Reading, UK

\begin{abstract}
Socialism produces distinct forms of humorous ridicule that are relatively rare in capitalist, bourgeois democracies. These forms are arranged in a hierarchy that reflects the distribution of power in this type of social and political order, one which differs markedly from a bourgeois democracy or indeed even a traditional or dictatorial authoritarian society. Merely authoritarian societies lack the kind of over-riding ideology and central control of economic and cultural life that are the defining characteristics of socialism. Socialist humorous ridicule is cruel at the top; then comes an aggressive and admonishing, but in intention humorous, official ridicule employed by the state in pursuit of centrally defined political ends. Finally, there is the ridicule by ordinary people of the elite and the social order they have imposed on the masses who respond by spontaneously and autonomously inventing and circulating innumerable jokes and anecdotes. This pattern is a product of the exercise of a monopoly of political and economic power by the leaders of the Communist Party and the distinctive political inequality that characterises socialism, an inequality based not on ownership but on differential access to the power of the state. The rulers of merely authoritarian societies that were not socialist such as Franco's Spain, Pinochet's Chile or Afrikaner South Africa did not and could not attain the same kind of hegemony that was possible under socialism because there existed economic, religious, scientific and even legal institutions that enjoyed a substantial degree of independence from their political rulers. Accordingly, they did not exhibit to anything like the full extent the patterns of humour to be found under socialism. The aggregate patterns of humour in socialist societies must be treated not as interactions between individuals but as 'social facts' to be understood in relation to other social facts, notably the nature of political power, with both sets of social facts being contrasted with those to be found in the capitalist democracies that are the antithesis of socialism.
\end{abstract}

Key words: cruel humour; jokes; macro-sociology; propaganda; ridicule; socialism. 


\section{Introduction}

In the socialist countries there existed three kinds of political humour involving ridicule that were far more common and important than in their antithesis, the capitalist, bourgeois democracies. Each of these forms of humorous ridicule was closely related to the nature and distribution of power in a socialist society and they can be regarded as a distinctive aspect of a socialist society. These were the cruel ridicule that could be employed with impunity by the socialist elite, the centrally controlled, tendentious, sometimes aggressive, sometimes admonitory, published ridicule provided by the professional humorists serving the socialist state, and the massive spontaneous ridicule of their rulers by the ordinary people through jokes and anecdotes. Only in National Socialist Germany (1933-1945), another totalitarian society with a single dominant party and ideology that penetrated all the institutions of society and crippled their autonomy, can we find any kind of parallel pattern (Gamm 1979; Hillenbrand 1993; Herzog 2012).

A socialist society is by definition one in which the private ownership of the means of production and distribution such as a factory, a farm, a shop or a warehouse has been effectively abolished and its restoration forbidden. Individuals are not permitted to own productive property (Sloan 1937: 43). The second defining characteristic of a socialist society is that it is governed by a single Communist ideology, which states that the present dictatorial socialist order is a transitional stage on the road to Communism, a happy land, far, far away, which when attained will be so productive that the division of labour will be abolished, people will only work as they choose to and all irksome economic constraints will have vanished (Marx 1875; Sloan 1937: 280-281).

The Soviet Union with its satrapies and satellites, the People's Republic of China, Cuba, Vietnam, Cambodia, North Korea and Ceauşescu's Romania between them, constituted the bulk of the world's strictly socialist nations with these characteristics and their overall area and population were such that for all intents and purposes they can be seen as having constituted the socialist world. Here we shall largely concentrate on Eastern Europe but there was and is similar joking in China (Ding 2013; Chey 2014) and in Cuba (Arkhipova \& Alejándrez 2014). The ruling ideology in these societies was Marxist-Leninist and all power was held by a single party devoted to that ideology (Carew-Hunt 1963: 187-188). In such a society, not just private property but the other institutions that define and characterise a bourgeois society, notably political parties competing to win elections, a constitution whose provisions are respected, an independent judiciary, a free press and a vigorous civil society (Shils 2006: 142-144; Butler 2013) did not exist. The state controlled the press and broadcasting and it could be very difficult to obtain independent access to a photocopier and even type-writers might have to be registered with the police (Cochran 1989: 265). Not surprisingly, the rulers of the socialist State depended very heavily on the use of force to prevent any infringement of their monopoly of political, economic and cultural life. Ultimately, all states depend on force to survive but in a bourgeois democracy it is kept in reserve. In the socialist societies force was right at the centre of the social order, notably that employed by the secret police, the Cheka-OGPU-NKVD-KGB, the Stasi and the Securitate. Without these the system would have collapsed at an early point and when that prop was removed in the late 1980s it meant the total and rapid collapse of socialism in Europe (PryceJones 1995). All that had seemed solid melted into air.

We may then regard a socialist society as one primarily stratified by party, by differential access to and control over the power and resources of the state; the different strata 
of such a society defined in this way produced and used very different kinds of political humour and ridicule.

\section{The cruel political humour of the elite}

Cruel humour cannot be defined. It can only be demonstrated. Where better then to begin than from an incident in the life of Stalin, a cruel tyrant with a keen sense of humour. Simon Sebag Montefiore writes:

Weeks later (after the execution of Zinoviev and Kamenev) at a dinner to celebrate the founding of the Cheka (secret police) Pauker, Stalin's comedian, acted the death and pleadings of Zinoviev. To the raucous applause of the Vozhd (roughly, supreme leader) and Yezhov, plump, corseted and shiny-pated Pauker was dragged back into the room by two friends playing the role of guards. There he performed Zinoviev's cries of 'For God's sake call Stalin' but improvised another ingredient. Pauker, a Jew himself, ... depicted Zinoviev raising his hands to the Heavens and weeping, "Hear oh Israel the Lord is our God, the Lord is one". Stalin laughed so much that Pauker repeated it. Stalin was almost sick with merriment and waved at Pauker to stop (Sebag Montefiore 2004: 202; see also Robert Conquest quoted in Amis 2003: 217218 and Rayfield 2004: 198-199 both of whom confirm Sebag Monefiore's account and Laughlan 2009 for a broader discussion of Stalin's cruel humour).

Sebag Montefiore comments in a footnote that Stalin's political rival in the Communist Party, Zinoviev, born Ovsei-Gershon Apfelbaum, was unlikely to have recited the Shema, a prayer that lies at the heart of the morning and evening prayers of the Jews and which traditionally are the last words spoken by a pious Jew on the point of death. Like the other Bolsheviks, he despised religion but it is maybe just possible that in extremis he recalled it from his childhood. It might be added that Pauker clearly did know it and that Stalin inferred its significance and relevance to Zinoviev's situation. Karl Pauker, a senior official under Yezhov, the head of the NKVD, formerly and still at that time, colloquially, known as the Cheka, was himself executed in 1937. Stalin was clearly very amused at this sadistic little charade performed for him at the dinner for his secret police. He greatly enjoyed the humiliation of his political colleagues as well as opponents, particularly picking on and mocking those who were Jewish (Vaksberg 1994: 57), and would have relished Pauker's willingness to demean himself by mocking the death agony of a fellow Jew in an anti-semitic way. It makes no sense to say that this incident was not funny. It is merely offensive to decent people but it clearly was very funny to those present at the dinner. That they laughed so much reveals that they had a cruel sense of humour but then what is to be expected of men whose trade was cruelty, men who were the willing and often enthusiastic servants and supporters of a cruel social and political order (Conquest 1971; Courtois 1997).

Many popular jokes exist (see Krikmann 2004: 47, 61, 100) that link Stalin's ruthless policies to his cruel sense of humour. The particular joke below was told to me by a RussianJewish émigré from Moscow:

Stalin, Roosevelt and Churchill had an argument as to which of them was able to get a cat to eat mustard. Churchill hid a little mustard in the cat's favourite treat, stroked the cat and gave it the titbit. The cat refused to eat it. Roosevelt now took the mustard 
and ground it and the titbit together to make a smooth paste. The cat still declined to eat. Stalin now smeared the hot mustard on the cat's arsehole. The cat howled and desperately tried to lick it off. "You see", said Stalin, "the cat did it of its own free will... and with songs" (for other versions see Vazsonyi 1998: 162; Krikmann 2004: 112; Nolly 2012).

Another anecdote has a similar point:

Stalin ordered the marshals of the Soviet Union to wrestle in front of him. Marshal Tukhachevsky won every single bout. Stalin was angry. He sent for Marshal Timoshenko, who was huge.

Timoshenko easily defeated Tukhachevsky. When Tukhachevsky was thrown to the floor, he banged his head. Timoshenko said he was sorry.

"Don't worry, comrade Timoshenko," Stalin said. "He won't be needing his head much longer" (see Perakh 1998).

Tukhachevsky, one of the Soviet Union's most able senior commanders, was killed by the state in 1937. Three of the five other marshals, 13 of 15 generals, 50 of 57 army corps commanders, and 154 out of 186 division commanders vanished in the great purges of 19361939. During the purges, absurd and impossible, confessions of guilt were forced from the accused by torture and by threatening to torture and murder their wives and children as well. Children over the age of 12 could be sentenced to death under Soviet law in the 1930s (Tolstoy 1981: 219) which gave it an utterly spurious legality. The loss of all these officers was one of the reasons why the Soviet army performed so badly during the invasion of Finland, a much smaller country, in 1940 and again in the early stages of the German invasion in 1941, when the Red Army fared worse than that of the Tsars in 1914. Timoshenko for a time held an important command. What is most interesting about the joke is that it ascribes to Stalin a moment of grim humour at the impending execution of someone well-known to him.

The occasions of Stalin's glee in tormenting Zinoviev was by no means a unique event in a system that both generated and tolerated such humour to the delight of the members of the Communist elite who both controlled and embodied it. In 1968 the historian Tibor Szamuely (1925-1972), a nephew of the man of the same name who had been the brutal People's Commissar for Military Affairs of the short-lived Hungarian Soviet Republic of 1918 , told me of an incident in the life of the economist Eugen "Jenö" Varga, who had been Minister of Finance in that same revolutionary government. Szamuely the younger had known Varga in Moscow, where his family had gone to live after the collapse of the revolution in Hungary, as had Varga who had become so influential that he was known as "Stalin's economist". Szamuely told me that Varga would regularly spend an evening playing cards with Lavrentiy Beria, head of the NKVD from 1939 and later deputy Prime Minister, the man whom with playful humour Stalin accurately introduced to Churchill as "our Himmler" (Service 2001). Varga had learned that the wordy Marxist theorist György Lukács, formerly Minister of Culture in that very same Hungarian revolutionary government and also now based in Moscow, was threatened with arrest and execution. One evening when they were about to play cards, Varga pleaded with Beria not to have Lukács executed. Beria said with amusement that Lukács' fate should be decided by that evening's game. If Varga won, the wretched Lukács' life would be spared. If Varga lost, then Lukács would disappear, as so many other foreign Communists living in Moscow had done. Varga managed to win and Beria, for whom both cards and executions were just an amusing game, kept his side of the 
bargain. It is very unlikely that such a witty but deadly wager would or could have been made by politicians in a bourgeois democracy, the kind of society that Lukács spent his entire intellectual life trying to undermine and destroy. This gives an ironic twist to the entire story and since Lukács had survived, it was possible for Szamuely to tell his story as an amusing tale over lunch and to bring out this irony.

One can imagine a writer of the calibre of Sir Tom Stoppard writing a black comedy about a socialist philosopher constructing mental systems of a kind that when put into practice would lead to his own life depending on the chance way in which a pack of cards was dealt. It would become a political parable about the essential nature of socialism, rather like Sir Tom Stoppard's (1978) Professional Foul, first shown in 1977, a play with a serious message about the Czechoslovak Socialist Republic but permeated with games and humour.

Some may try to reduce these distasteful pieces of inter-personal humour to mere characteristics of the particular individuals who have been named in the text. This is to miss the point. Far more important is the fact that monsters such as Stalin, Mao Zedong, Pol Pot, Kim Il Sung, Che Guevara, Mengistu Haile Mariam or Nicolae Ceauşescu were far more likely to enjoy political power and to have far fewer checks on and limits to that power in a socialist society than would be the case in a bourgeois democracy. The official attempt in later years to blame the system's cruelty on Stalin alone and to use as a counterweight 'grandpa Lenin', gentle Lenin meek and mild, is quite simply a lie (Amis 2003: 29-30, 114, 138, 236). Lenin was not only a cruel and ruthless murderer on a mass scale (Maximoff 1975) but was amused by tales of violence. The progressive intellectual H. G. Wells who had interviewed him in 1920 said he laughed a lot but called his laughter 'grim' (British Intellectuals Visit Moscow 2014). David Pryce-Jones (1995: 11) records that "After an interview with Lenin, the philosopher Bertrand Russell commented, 'His guffaw at the thought of those massacred made my blood run cold'". Russell's comment is also recorded by Conquest (2005: 93). There is an implicit truth in the joke told in Russia at the time of the official, cultic celebration centenary of his birth in 1970:

Lenin's widow, Krupskaya, visited a school to tell the children what a wonderful man Lenin had been and in particular how kind he had been to children. "One day", she said, "Lenin was standing outside his dacha, peeling an apple with his knife. A hungry little boy came and watched him and asked him what he was doing. 'Can't you see, little boy', Lenin said, 'I am peeling an apple"'. The children in the school were puzzled. "How does that show how kind Lenin was?" one of them asked. "Don't you see", said Krupskaya in a fury, "Lenin could have cut the hungry little boy's throat but he didn't" (told to me by Professor Alexander Shtromas in 1980; for variant versions see Zand 1982: 67; Sturman 1984: 220).

Furthermore, it can be can predicted with some confidence that a detailed examination of the behaviour of socialist elites would reveal many other examples of a cruel, mocking humour of this kind, a humour which in bourgeois society is more characteristic of deviants outside the main political system, such as gangsters. Democratic politicians are often thieves or fraudsters but rarely gangsters. Bullies with a cruel sense of humour can and do rise to the top in democratic politics but they are much less able to employ it against those around them in the kind of unrestrained way that socialism permits. Were they to do so as blatantly, the press and the opposition politicians would get to hear about it and it would be used against them. It is these structural factors that are crucial rather than the personalities of individuals. It need hardly be added that the arbitrary executions that gave rise to the particular instances of 
humour cited above would not be possible in a society where the rule of law is respected. The cruel humour and ridicule of socialism was but one consequence of a world in which cruelty was common-place, the cruel and arbitrary infliction of death, torture, and exile with slavery. It could even take the form of the public humiliation, through cruel mockery, of a hapless political opponent or supposed opponent charged with a purely political offence. Here we see the real use of humour as a weapon, cruel humour used as a political instrument. Wit and humour are completely ineffective as a means of attacking a political system (Davies 2011a: 245-252) but they can be used by those enjoying power in a socialist society utterly to destroy a particular individual. In a bourgeois democracy the worst that politicians have to fear is a humorous put-down at the hands of a quick and witty opponent such as Clémenceau or Lloyd George that is then good enough to get into the history books. It is a world apart from the humiliating humour directed at individuals in a formal context under socialism described by Iain Lauchlan.

The cruelty of Stalinist laughter escalated in tandem with the brutality of the purges. Bukharin was no longer cracking jokes when he mounted his last defence against accusations of treachery at the Central Committee plenum of February 1937. Nevertheless, the audience of accusers -hysterical, terrified and vicious- found his wheedling attempts to escape death hilarious. 'Why are you laughing?' Bukharin whined. 'There is absolutely nothing funny about any of this' (Lauchlan 2009: 261).

Here is a part of the transcript of Bukharin's ordeal to which Lauchlan refers:

Bukharin: I won't shoot myself because then people will say that I killed myself so as to harm the Party. But if I die, as it were from an illness, then what will you lose by it. (Laughter.)

Voroshilov: You scoundrel! Keep your trap shut! How vile! How dare you speak like that!

Bukharin: But you must understand - it's very hard for me to go on living.

Stalin: And it's easy for us?

Voroshilov: Did you hear that: 'I won't shoot myself, but I will die'?

Bukharin: It's easy for you to talk about me. What will you lose, after all? Look, if I am a saboteur, a son of a bitch, then why spare me? I make no claims to anything. I am just describing what's on my mind, what I am going through. If this in any way entails any political damage, however minute, then, no question about it, I'll do whatever you say. (Laughter.)

Bukharin: Why are you laughing? There is absolutely nothing funny about any of this.....

Bukharin: Whatever they are testifying against me is not true. (Laughter, noise in the room.)

Bukharin: Why are you laughing? There is nothing funny in all this.

(Getty \& Naumov 1999: 370, 394)

Bukharin is wrong to say that "There is nothing funny in all this." Bukharin's listeners, his Party comrades, clearly did not agree with him, for they laughed repeatedly. It was funny for them, if not for Bukharin. Humour is not necessarily good humoured, nor to use one of Stalin's favourite words 'jolly or joyous' (Petrone 2000). Stalin had actually liked Bukharin as a person but this did not inhibit him from taking part in the goading ridicule of him; the 
trial ceased to be a mere impersonal necessity of state for Stalin and became an occasion for personal mockery. Nor is a laughter of triumph necessarily devoid of a humorous component. Rather we are here at the very edge of humour, just on the humorous side of the line at which cruel humour becomes humourless cruelty. The audience did not have to laugh at Bukharin; they could have booed him or simply remained grimly silent but they chose to be amused. It was a political act and a product of the political system...

The exchanges involving Bukharin would be funny to outsiders too, if they were fictional, as, say, part of a black comedy such as Anthony Shaffer's (1970) Sleuth or David Halliwell's (1967) Little Malcolm and his Struggle against the Eunuchs. When an imagined event takes place on stage or in a film there are no limits to the level of brutal ridicule that theatre-goers and film-watchers will choose to witness and to laugh at; they are regularly amused by things that would horrify them in real life. But it is almost impossible for outsiders living in a bourgeois democracy to share with the socialist elite their amusement at real and deadly events. Their inner commitment is not to socialist ideology and power, which would be amusement-enabling, but to bourgeois morality, which makes them feel sympathy and pity for the person being reviled and tormented for other's amusement. They come from a social world with utterly different values and are unable to easily over-ride them.

Cruel humour used as a political weapon under socialism was not limited to the Soviet Union under Stalin, nor to the immediate entourage of the supreme leader. Such humour was an essential part of Mao Zedong's Great Proletarian Cultural Revolution, 1966-1976, in which Mao sought to purge the Party and the bureaucracy in order to restore the purity and full enforcement of socialist ideology (Lifton 1967, 1970; Urban 1971). During Mao's ultrasocialist Great Leap Forward of 1958-1961 about 40 million Chinese had been worked, beaten or starved to death (Dikötter 2011) and far from being an economic leap forward it was a clumsy sprawl backwards (Shapiro 2001). Mao was now heavily criticised by the moderates in his own party, the 'capitalist roaders' who would later bring capitalism and a previously unknown degree of prosperity to China after Mao's death. The unleashing of the Cultural Revolution by Mao was a device to prevent the weakening and diluting of socialism by his more pragmatic colleagues and thus to restore his own supreme and unchallenged position. Accordingly, he mobilised the Red Guards, an armed revolutionary youth organisation, who aimed to render first China and then the rest of the world utterly 'red'. Blind enthusiasm replaced technical expertise and a frenzied xenophobia prevailed. The Guards attacked not only institutions but people, particularly in the years 1966-1968.

An important aspect of these attacks was the public humiliation of particular individuals by jeering, laughing crowds of young radicals. These events have been strikingly recorded for us by the photographer Zhensheng Li (2003). In a photo taken on 12 September 1966 the Red Guards can be seen literally tearing out the hair of a provincial governor whom they had deposed, because he had dared to have his hair cut in the same fashion as Mao himself, thus imitating his sacred baldness. A further photograph of 24 August in the same year shows Buddhist monks in Harbin, Manchuria, being paraded by the Guards and being made to hold up banners saying "To hell with the Buddhist scriptures, they are full of dog farts". Had the monks resisted being made the victims of scatological political humour, they would have been beaten up and killed. As indicated in the bibliography, Li's historic photographs may be viewed online, as may the photographs of Jews being forced by the Nazis to scrub the streets of Vienna in 1938 with grinning officials and crowds clearly amused by the spectacle (Magnolia Box n.d.). Such a scene would have been unthinkable in Austria under the merely authoritarian regimes of the Emperor Franz-Joseph or the Clerical-Fascist Chancellor Kurt 
Schuschnigg who was overthrown by the Nazis in 1938. Levels of ridicule are a function of the degrees of inequality of power.

The mechanisms involved in these singularly nasty events described above are recognisably those of humour and those taking parts on the persecuting side were amused as well as frenzied. Laughing at ridiculed individuals is a part of everyday life in bourgeois societies and may be used as a means of informal social control (Bergson 1963 [1924]) when it can be severe (Billig 2005), but it is rarely cruel and certainly not on a socialist scale. There are socially imposed limits and, if they are exceeded, other individuals will intervene or bring sanctions to bear; they are able to do this because power is dispersed. It is common enough for an actor to be grossly humiliated and ridiculed on stage, as happens in many farces (Milner Davis 2003) but such incidents would be seen as grossly deviant and calling for intervention if enacted off-stage. What has happened in the socialist incidents I have described above is both a greatly magnified version of everyday ridicule and a moving of the nastier aspects of stage humour into real life. The shift in the intensity of the ridicule and the move from the imagined to the real transforms the harmless into the destructive, the trivial into the repellent. But the humour was and is there for those who set up and relish nasty events of this kind. Even those of the participants who are basically decent people may feel joyful and liberated because they have escaped the usual constraints of human society and of their own conscience, which, in a much more limited way, is an aspect of most humour. Jokes briefly and enjoyably evade conventional constraints, but after the joke telling session the joke-tellers return unchanged to the everyday moral world. Ideology, by contrast, has the capacity to destroy the moral world altogether in the name of an abstract 'higher ethic' and to unleash forms of demonic laughter which would be abhorrent in a bourgeois democracy.

\section{The second level of ridicule and humour under socialism}

Below the socialist elite, who can, if they choose, indulge in or incite a humour of direct cruelty, comes a segment of well-paid but utterly subordinate writers and artists skilled in ridicule. They have little possibility of alternative employment. Their talents are deployed to demonise the regime's opponents through mockery and also to ridicule lower level functionaries whose activities frustrate the public or to jeer at workers or peasants seen as lagging in enthusiasm. The ridicule produced by this class of creative intellectuals that is and will be best remembered is visual, taking the form of posters and cartoons, which even today and to those who abhor the causes they upheld remain vivid and often amusing. It was political humour in the service of the State and the Party, one aspect of the vast flow of propaganda and exhortation that sought to give a cosmetic legitimacy to a system based on force. Because and only because such work is produced by particular, often named, individuals and directed and censored by a single, if at times chaotic, authority, it is possible and permissible to suggest the functions their output performed, something that cannot and should not be attempted with jokes.

Socialist regimes need enemies. Their central ideology is one of class conflict and so there have to be class enemies everywhere, both at home and abroad and officially sponsored cartoons ridiculing capitalists, aristocrats, industrialists, bankers, kulaks and clerics chastise the real and invented enemies of socialism (Aulich 2005: 12). Because there is, in theory at least, one pure ideology upheld by a single united vanguard party, when divisions within the single ruling party over ideology or policy do occur, they tend to result in expulsions and persecution and those expelled have to be demonised by the same cartoonists (Yefimov 2005: 
$27,56,63)$ who yesterday lionised them. Furthermore, there is an endless need for scapegoats to blame for the inevitable failures of a system of central planning supposed to be infallible, and so 'wreckers' and 'saboteurs' have to be invented; they are one more class of traitors to be denounced (Pryce-Jones 1995: 11). Humorous ridicule by means of political cartoons and posters is a way of making all these enemies, whether real, absurdly magnified or utterly imaginary, appear weak as well as powerful, and foolish as well as hateful, so that victory over them is assured.

The posters and cartoons are often aggressive (Norris 2013), indeed, in a purely metaphorical sense, violent. They live in the border-land between seriously aggressive humour and pure aggression. This is also true of the work of some of the cartoonists and caricaturists working in an open society but the latter not only hold very diverse political views but sell their work to or are employed by an equally diverse range of newspapers and magazines. Also, editors may wish to avoid affronting readers with too aggressive a humour because the readers are free to take their custom elsewhere. The editors and proprietors may well employ cartoonists the thrust of whose work differs from the editorial line of the publication. In such an environment they tend to lack the lethal certainty of their socialist colleagues, who have to do what they are told.

The posters designed for bourgeois governments are quite unable to match those produced under socialism for sheer fight and boldness; those who commission them and those who execute them are undermined by that sense of fairness and moderation which is so central to their society's culture. The government posters of democracy are often funny but in a curiously cosy and whimsical way (Judd 1972: 100-102, 107-108; Aulich 2007: 172) and they rarely show a mastery of vicious humorous ridicule. Even in wartime they were rarely able to produce posters that can match the ruthless humour of the Soviet or Nazi ones (see Judd 1972; Bryant 1989; Lamonaca \& Schleuning 2004). During the Second World War senior administrators at the British Broadcasting Corporation, in effect a state monopoly but with considerable autonomy, agonised about whether to permit jokes on the radio about Marshall Hermann Goering (head of the German air force then bombing London) being very fat, for such jokes were seen as being stoutist, an unacceptable form of ridicule making fun of a physical defect (Davies 1996: 37), but the official Soviet cartoonists had no such qualms and also depicted the crippled and undersized Nazi leader Goebbels as a comic, deformed midget (Bryant 1989: 130). The BBC condemned jokes about the destruction of German cities by the RAF as a form of unacceptable gloating and banned them altogether (Davies 1996: 4243) but a humour of gloating at injury and devastation inflicted on an enemy was standard stuff for the Soviet cartoonist (Judd 1972: 22-23).

The nature of socialist visual ridicule and the difficult situation of those who produced it are well seen in the admissions made in interviews in his old age by the greatest of all Soviet cartoonists Boris Yefimov (1899-2009). After 1945 he was suddenly told to use the images he had devised for ridiculing the Nazis during World War II to mock the Western leaders Truman, Churchill and Ernest Bevin (the British Foreign Secretary, a former lorry-driver). In one cartoon from 1946 Churchill, girt with grenade, pistol and dagger, is shown dancing before a microphone in Fulton, Missouri and his shadow resolves itself into the easily recognisable heads of Hitler and Goebbels (Yefimov 2005: 110-111). In an interview Yefimov (Interviews 1999) said:

Cartoons are the first thing that a reader of a newspaper looks at. He takes it in more quickly and more completely than any long article you would read. A cartoon 
instantaneously gives you both the event and the commentary about that event. That is the nature of a cartoon: fast, funny and persuasive.

If you need an example here is one: I was often impressed by Churchill, by his will, by his wonderful oratory talent, his jokes. I really liked him. And then it was announced that he was our enemy, and we had to draw cartoons about him, and when I drew him looking in the mirror and seeing a reflection of Hitler, that was, for me, not convincing and not pleasant... I understood that this was not true, and I didn't believe it in my heart, in my soul, but that was government policy, and it was a situation against which I could not act.

Kevin McNeer (2009) said of Yefimov (his name can also be transcribed from the Cyrillic as Efimov):

I challenged him about his support for Stalin's purges, his drawings during the infamous Show Trials of the 30s, when Efimov published vicious political cartoons against his friends, including Bukharin and Trotsky, depicting them as Nazis and spies when he knew the accusations against them were false. The cartoonist was sent by Izvestia to cover Bukharin's trial, and it was expected that he would portray Bukharin as guilty... (Yefimov now said) "What was I supposed to say when I heard with my own ears how he confessed that he was a traitor, a turncoat, an enemy of Soviet power? It was a complicated time. Now it's fine to criticise. I am not Giordano Bruno to burn at the stake on a matter of principle. I knew that if I said, 'No, I won't!' I would end up in the very same place. My family, my wife would be killed. I recall those cartoons with aggravation, with shame, with disappointment, but I couldn't have acted differently then."

Below these cartoons of high politics came the cartoons of exhortation through ridicule, which were also part of the politics of blame. Those in power consistently tried to shift the blame for the system's economic failure onto those below - low-level officials, collective farmers, shop managers and assistants. The ordinary workers in a badly performing factory might even be paraded through the streets and exposed to rituals of public shaming. Individuals with a grievance were encouraged to complain about minor functionaries both to those in power at the centre (Pryce-Jones 1995: 55) and to the press and after suitable screening their letters might get published (Davies 1997: 18, 37; Thurston 1991: 551-553; see also Low \& Martin 1932: 88-89). This pretence of democracy was one more form of control from the top and a way of diverting discontent onto the little man. Letters complaining about hunger, cold, shortages and the oppressiveness of official regulations never got into print (Davies 1997: 31). All the shortcomings of the socialist order were blamed on a few deviant individuals (Deriabin \& Gibney 1960: 73, 113, 136). The humorous ridicule of these scapegoats was central to official socialist humour, which sought to deride as well as entertain. Throughout the socialist world journals with biting and stinging names such as Krokodil, Nettles, Porcupine, Hornet, Stag Beetle, Thistle were a vehicle for satires and cartoons that bit and stung those with a little brief authority who had to face workers, clients and customers directly. It was a humour of scorn and indignation that did not extend to the powerful and editors could be sacked for aiming too high in their choice of target (Talmadge 1943: 46; Chamberlin 1957: 27; Sanders 1962: 22-27; 1982: 21-29, Oring 2004: 216). The most unpredictable danger was that one of the little people who had been made fun of might rise through the system and become powerful enough to take revenge as happened to the 
Soviet humorous writer Emil Abramovitch Draitser who ruefully commented "In the Soviet Union it is not enough to know who's who, you have also to know who will become who" (personal communication; 1979). In the appendix to his book Forbidden Laughter: Soviet Underground Jokes (Draitser 1978), published after Draitser had moved to America, there is a spoof anonymous denunciation of himself as editor and compiler signed 'A Well-Wisher' - in the best socialist tradition.

Two of the greatest sources of popular discontents were the shortage and poor quality of food and housing due to the collectivisation of agriculture and the diversion of the construction industry into giant projects doomed to fail - the socialist fetish of investment. This is why venal store-keepers and ware-house managers and deficient construction figures and restaurant staff were such favoured subjects of cartoons (see Montague \& Marshall 1943: 60; Editors of Krokodil 1989: 74, 86, 95, 101, 121, 123). Likewise the porcine featured "heartless, greedy and rude bureaucrat" could be ridiculed but only when was made clear that he was a mere functionary and not the divine representative of the Communist Party (Talmadge 1943: 47; Thurston 1991: 551-553; Kozin 2009: 223).

Among the key scapegoats to be made the focus of humorous ridicule were the drunks and heavy drinkers, notably after Gorbachev began his anti-alcohol campaign to try to reverse the huge rise in alcohol consumption and abuse that had taken place in the immediately preceding decades when it had been used as a source of income for the state and an opiate for the people. By Brezhnev's time, the consumption of vodka was six times what it had been in 1926 and there were "40 million officially acknowledged alcoholics" (Pryce-Jones 1995: 79). Latterly the increase had occurred because there had been a large increase in money wages but no consumer goods to spend it on except vodka and vodka was an escape from the realities of socialism. But the politics of blame made the drunkards the cause, not the consequence of the society's economic and social problems.

Depictions of comic drunks and drinkers exist in many societies but only in official Soviet humour have these been systematically used as part of an exhortation to higher productivity in the work-place and even as part of an attack on keeping religious holidays (Lafont 2007: 58, 186-187, 210, 243) that lead to workers taking a day off. The conscription of the comic boozer by official humour provides an excellent illustration of the contrast between official humour and the humour of the ordinary people expressed through the anecdotes.

\section{Planned ridicule and spontaneous ridicule under socialism}

Official humour is planned ridicule. It follows patterns laid down by the authorities and fulfils explicit political purposes. Jokes, the humorous ridicule of the people, lack purposes and functions and are much more varied, which does not mean that we cannot discern ordered patterns in them that can be linked to the social order. It is spontaneous as opposed to designed order (Polanyi 1951; Barry 1982). In Western societies jokes and humour about alcohol are linked to ethnicity, religion, social class, gender and other social variables in discernible patterns that were not planned but emerged from the everyday interactions and observations of ordinary people (Davies 1998: 101-136). Only in the Soviet Union and Eastern Europe did many of the jokes about drunks and drinking become political jokes, part of the general pattern of jokes mocking the political system that were so universally popular. 
The theory of historical materialism indicates that the intermediate stage between Socialism and Communism is alcoholism (in oral circulation; see also Lewis 2008: 166).

A drunk fell into a sewer and could not get out. He clutched the bars and tearfully cried out, "But for what, comrades, for what?" (in oral circulation; see also Beckmann 1980: 21).

A new assistant was being taken on at a 'vytrezvitel', a sobering up station in Russia. "What do you do with the drunks?", he asked. If they smell of vodka we send them back to their factory. If they smell of samogon we send them back to their village. "But what do I do if I get someone who smells of cognac?" "In that case he's a senior party official, so you clean the vomit off his suit and send him home" (Davies 2011a: 215).

On a visit to Moscow President Eisenhower saw very many drunks. He asked Khrushchev about it. Surprised, Khrushchev replied "You mean there are no drunks in Washington?" "No", answered Eisenhower adding ironically, "When you come to New York, you have my full permission to shoot the first three drunks you see." Six months later Khrushchev came to New York and went for a walk that evening. He shot the first three drunks he saw, and then went back to sleep. When he woke up the next day, he found a report in the Washington Post: "Short Bald Gangster shoots three employees of the Soviet embassy" (in oral circulation; for another version see Skrobocki 1992: 21).

Let's have a drink Vladimir Il'ich! I can't old man. I'm on the wagon. Yesterday I drank a lot at the Finland Station, climbed on an armoured car and said such nonsense that I still can't figure out what happened! (Graham 2003: 76, note 101; for another version, see Sturman 1984: 205).

The comic and disgusting drunk who was so ubiquitous a figure in Soviet socialist society is still a key player in these jokes but the main focus of the mockery has moved away from him to the political system. The jokes ridicule instead (a) the messianic political ideology that promises communism, (b) the pattern of arbitrary arrests and imprisonment for no good reason, (c) the rigid stratification by party of a supposedly equal society, (d) the inability of Khrushchev to understand basic social realities, and (e) the speech by Lenin at the Finland Station on his return to Petrograd in 1917 to start the Bolshevik seizure of power. The jokes accurately identify the very essence of the socialist system and ridicule it. Yet no-one designed and set up this pattern. Jokes about boozers, drunks and alcoholics with no political twist were common enough in the socialist societies and were much the same as in the bourgeois democracies. The difference is that, in the socialist societies where political criticism was forbidden, the jokers indirectly evaded the prohibitions on adverse comment and made drunks one more vehicle for the political ridicule of their oppressors. The political jokes did not displace the jokes about drunks but simply added new versions that were now part of the huge corpus of political jokes under socialism. Admonitory ridicule belongs to those who hold political power; mocking political jokes are the property of the people. Humorous admonition is ridicule of $u s$ by them but jokes are ridicule of them by $u s$. 
The political jokes about the drunks cited above are merely one aspect of the universal political ridicule of the socialist order through jokes. The topics differ but the central thread remains. The examples below are all translations from Romanian and reflect local conditions but such jokes were told throughout Eastern Europe under socialism:

How many kinds of electric current are there in Romania?

There are two main kinds: continual current (DC) and alternating current (AC). But the alternating current is, itself, of two types: continual-alternating and interruptedalternating. And the interrupted alternating current is, again, of two types: continually interrupted alternating and alternating interrupted alternating (Cochran 1989: 265).

What is the difference between Hitler and Ceauşescu?

Hitler turned on the gas (Cochran 1989: 265).

The two Romanian jokes above refer to the regular disruptions of the supply of fuel and power to Romanian households that made the life of the ordinary Romanian citizen cold, dark and miserable under Ceauşescu, especially in the bitter winter of 1984-1985. The energy had been diverted into huge, badly managed investment projects where it was wasted.

Ceauşescu is making a speech at the opening ceremony for the Danube-Black Sea canal. He begins "Friends, countrymen, sailors." One of his deputies pulls at his sleeve.

"Not now," he whispers, "I am trying to make a speech."

He begins again: "Friends, countrymen, sailors."

But again there is the persistent tug at his sleeve.

"Mr. President," whispers the deputy, "the men in the striped suits are not sailors" (Cochran 1989: 266).

During Nixon's visit to Romania President Ceauşescu asked him how many poor people there were in the United States. "About 20 million," Nixon replies. "Very interesting," says Ceauşescu, "It's exactly the same number as in Romania" (Brunvand 1973).

Three archaeologists from America, Russia and Hungary dig down into the ground. The American digs down and finds a wire. This proves that Americans invented the telephone a thousand years ago. A Russian digs down and finds nothing. This proves that Russians invented the wireless one thousand years ago. A Hungarian digs down and finds excrement. This proves that two thousand years ago Hungarians laid the foundations of Socialism (Banc \& Dundes 1990: 99).

How are things in Romania under Communist rule?

Wonderful. We live like on permanent Yom Tov.

What do you mean?

Well you see, we dress like on Purim, are housed like on Succoth and eat like on Yom Kippur (Banc \& Dundes 1986: 67). 
This last joke is clearly a joke invented and told by Jews living in Romania, the community to which the pseudonymous compiler C. Banc (banc means "joke" in Romanian) belonged. Yom Tov means a holiday in the Jewish calendar. On Purim, a day of carnival, it is permitted and expected to wear ridiculous garments. On Succoth it is customary to move for a week to live in a booth or 'tabernacle', a fragile temporary building with a roof made from pieces from a leafy tree or other vegetation. On Yom Kippur, the Day of Atonement, the holiest day of the Jewish year there can be no eating and drinking, no wearing of leather shoes, no bathing or washing and no sexual relations. That was the "multilaterally developed socialist society" of Romania, an agriculturally rich country with a shortage of food, a country where the construction industry suffered from utterly dysfunctional planning, and a country where contraception was banned, forcibly to boost the birth-rate of a dispirited people without heating, housing or hope.

The people, the oppressed, the victims of the great socialist experiment, that vivisection of the soul, were the anonymous inventers of thousands of these mocking jokes that ridicule not just their political rulers but the entire system. The individuals who wrote official humorous ridicule had purposes laid down by the powerful and their ridicule may have had the consequence of activating the activists, those already in sympathy with the purposes. But the ordinary joke-tellers were powerless and, however resentful they may have felt, their political humour and ridicule had no purposes and no consequences (Davies 2007, 2011). Jokes are so feeble a social force that they can neither seriously undermine nor by acting as a safety valve prop up a political order. Where there is no author there can be no purpose. To deduce tendentiousness from a text is absurd.

\section{The comparative dimension}

My thesis that the three levels of mocking political humour found under socialism, and which are but rarely found in the capitalist bourgeois democracies, are a product of the socialist social and political order needs to be tested against other types of society that do not belong clearly in either category. The thesis predicts that the closer a society is to the socialist type, the more closely its patterns of political humour and ridicule will resemble those of socialism. Most authoritarian societies are too distant from socialism to provide the full range of socialist humour. Their rulers may well be ruthless and even have a cruel sense of humour but they try to avoid creating external and internal enemies because these are bad for stability and their only real concern is not to be dislodged. These societies are stratified by class and status not by party and have no overriding ideology. The rulers have no wish to transform their society in pursuit of a distant messianic goal. Hence there exists much less in the way of official humour ridiculing enemies or mocking those lacking in enthusiasm. Authoritarian rulers of this kind may well end up transforming their societies as, say, Pinochet did, not by planning but through the operation of the market place. They often undergo a relatively painless transition to bourgeois democracy because they have pragmatically evolved in a democratic direction with a gradual freeing up of autonomous institutions such as the press or unions (Payne 1987) so that at the end not much needs to change. While there are very many jokes about an autocratic ruler such as Franco (García 1977; Pi-Sunyer 1979) or Mubarak (Ausaf 2009) or Putin in post-socialist Russia (Arkhipova 2009; Sheygal-Placzek 2009; Shilikhina 2013), there is no culture of mass joking about the entire social order. There will also be jokes ridiculing a variety of autonomous institutions within the society but these are not part of political humour since the institutions are not politicised or tightly controlled by the state. 
In contemporary China, where there is socialist rule with an authoritarian one-party state and a single hegemonic ideology but increasingly also a market economy and private wealth, there is a new cycle of jokes (Chey 2014), the Grandpa jokes (remarks put in the mouth of a naively outspoken old peasant, often replying to a question somewhat in the manner of Radio Erivan). Some of the new cycle still ridicule the socialist system but may also focus on new sources of economic power such as property developers, banks and health insurance companies. The targets of the jokes are going plural as economic power is dispersed.

What is urbanisation?

Grandpa replies: It is when the government buys your two mou of land for 8 thousand yuan, then sells it to a developer for 4 million, and then your sons take the 8 thousand that you got for the land plus another 8 thousand that the two of them had saved and go to the capital to work like slaves for 20 years (Chey 2014).

The society whose patterns of humour most closely resemble my model of humour under socialism was Nazi Germany. There was a cruel humour at the top and among those exercising violence on behalf of the state. The photographs of Jews being forced to scrub the streets of Vienna after the Nazi take-over of Austria in 1938 supervised by grinning clearly amused activists and members of the Hitler youth movement were the equivalent of the humiliations imposed by the Red Guards in China. Nazi posters attacking imagined external and internal enemies and demanding enthusiasm from the masses have the same splendour and humour as their socialist equivalents and once again in an evil cause. The Devil always has the best posters. Whispered political jokes, die Flüsterwitze, told after a sideways 'German glance', der deutsche Blick, to make sure nobody is listening were also pervasive under the Nazis (Hirche 1964; Gamm 1979; Hillenbrand 1993) although they were neither quite as extensive or ingenious as the ones told in the communist countries; only in the last years of the war was there a total mobilisation of resources and subordination of all other institutions.

Nazi Germany was, just like the Soviet Union, the conscious antithesis of bourgeois democracy, stratified by party and with four-year plans and compulsory labour service (Henderson 1940: 24, 58). All institutions were subordinated to the state and the leaders were determined to intensify that subordination in the future and in particular to eliminate the independence of the churches (Trevor-Roper 1973). Hitler and his Party also wanted a more classless society (Henderson 1940: 24, Schoenbaum 1966), one in which people of his own humble social background were respected and looked after, one in which all members of the Herrenolk, the master-race, were masters. Hitler also disliked the capitalist money ethos and was fearful it might undermine the spirit of the National Socialist revolution. On $23^{\text {rd }}$ January 1942 Hitler (1973: 236) said to his intimates: "Let's suppose that one day National Socialism will undergo a change and become used by a class of privileged persons who exploit the people and cultivate money. One must hope that in that case a new reformer will arise and clean up the stables." Shades of Mao.

Similar societies then produce similar patterns of humorous political ridicule. The similarity between National Socialism and Soviet Socialism was not lost on the jokers in socialist societies.

"Did you hear that they have renamed Bucharest?"

"No, what is it called now?" 
“Ceauşwicz” (Cochran 1989: 265).

A Russian Jew was walking through the suburbs of Moscow when a car stopped suddenly, a man was thrown out at the side of the road and the other car sped off. He ran over and saw that it was his old friend Moishe who had been beaten almost to death by the KGB and was nearly unconscious, his eyes opening and closing. "Moishe, Moishe", he cried, "It's me, Abram. Don't you remember me? We were in Auschwitz together". "Ah", said Moishe dreamily, "ah yes, Auschwitz" (see also Banc \& Dundes 1990: 39-40).

I hear that all the Germans in Nazi Germany are going to have a 'people's car' (each). That's nothing. We all have two vehicles, the NKVD car and the ambulance (Davies 1995: 97).

On Hitler's instructions the Volkswagen (people's car) was designed and was to be produced so that every family could afford a small car paid for by instalments. The factory was soon switched to making military vehicles. The NKVD was the secret police, descendant of the Cheka and ancestor of the KGB.

What is the difference between a tomato and a member of the Communist party?

There isn't any. They both turn red after having been green first.

Pre-war fascists in Romania wore green shirts as a symbol of renewal. After the Soviet take over many joined the Communists and became Reds. A parallel joke was told in Slovakia. Conversely, Hitler (1973) remarked that he could make a good Nazi out of a Communist but not out of a Social Democrat.

A tramp (in National Socialist Germany) needs a roof over his head, even if it is only that of a prison cell. So he goes up to a policeman, shouts "Rot Front" (Rot here signifies Communist, Red) and raises his clenched fist. The policeman pretends not to have heard or seen anything and continues on his beat. A column of storm troopers comes marching along, and the tramp repeats his performance. One of the SA men breaks rank and tells him off. "Are you nuts, mate? There in the third row we've got a Nazi!” (Larsen 1980: 44; Raskin 1985: 229).

These jokes can be seen in two ways. First, it is a recognition that the oppression and violence which the joke-tellers had experienced had a parallel in that inflicted by the Nazis, something of which joke-tellers in the Baltic States, Poland, the Ukraine and East Germany would have been particularly well aware. The Czechs too had lived under two cruel stars (Kovály 1986). Second, the jokers are ridiculing one of the central political myths of socialism, namely that it was the opposite of and the main opponent of fascism. The jokes defied, inverted and besmirched the centre piece of the official ideology. That is what effective humorous political ridicule does. It is no wonder that the authorities periodically tried to suppress popular joking, not because it had any effect but because it was all too accurately offensive. Yet it is doubtful whether for present purposes it is helpful to see the political jokes primarily as a weapon (Larsen 1980), as resistance (Zlobin 1996), or as a protective device for the recalcitrant (Waterlow 2013: 224); after all, even those who exercised power enjoyed the jokes (Deriabin \& Gibney 1960; Myagkov 1976). Playing with 
forbidden utterances is amusing even for those who do the forbidding. For critics jokes were a weapon and for the recalcitrant a shield but for the powerful they were a mere playing with the images of opposition. Jokes are playful devices for inducing laughter. They cannot be reduced to equivalent serious statements. They do not have an essence. They are necessarily ambiguous, which is why people of very different persuasions and having very different perceptions can all laugh at the same joke (Davies 1998: 178-180; Kosintsev 2009: 202, 208). The jokes remained very popular when translated into English, French (Isnard 1977) or when Radio Armenia appears in German (Schiff 1969) and consumed by people who had no direct experience of socialism. The latter may not have felt the full emotional force of the jokes nor did they invent new ones, but then neither did many of the individuals exchanging jokes in the socialist countries.

The ways in which people use jokes in a repressive society, the so-called 'pragmatics' of joking, uses such as their employment as political criticism (Zlobin 1996) or as cynical realism (Yurchak 1997) or to create a mental and social space that is an escape from the system and a reassurance of self-respect and autonomy, or to enjoy a brief piece of time off and a taste of freedom (Davies 2011a), or to find trust in a world where from an early age betrayal was encouraged (Bronfenbrenner 1974; see also Henderson 1940: 30) or to establish, display and cement solidarity and identity in a group (Waterlow 2013) is an interesting topic in and of itself but it is of no help whatsoever in the study of why particular aggregate patterns of jokes exist at all. All these 'functions' can after all be satisfied in non-humorous ways (Oring 2004). It is very difficult to know what was going on in the minds of the joke-tellers of the past, particularly when very similar jokes circulated in such culturally different countries as Estonia, Romania and East Germany, among the highly educated and the less educated, whispered in times of terror under Stalin and a ubiquitous entertainment in the decadent years of Brezhnev, among the Russians who became a dominant people and among the subordinate peoples of the Russia's satrapies and, of course, the Jews, intellectually important and very vulnerable. When contexts are so varied, any argument about sets of jokes that depends on context is built on sand. Jokes are by their very nature context-free and thus transportable; that is why they travel so quickly. The tone of a particular joke changes with each telling and it is impossible to add these up to provide a single coherent picture; indeed, it would be futile and foolish to try to do so. It never makes sense to try and explain the existence of a large aggregate of jokes by asking how individuals use them, whether it be jokes about Gabrovo in Bulgaria, about hrabia (counts) in Poland or about Belgians in France and this is equally true of the political jokes of socialism. It is necessary rather to concentrate on what we do know with some certainty, namely the ways in which the content of the political jokes under socialism, whether in its time of terror or its later age of decadence, differs from that of the jokes told in the bourgeois democracies and then to link this to the macro-social order rather than to seek explanations within the sliding, changing, incoherent interactions of small groups of individuals. The key difference is that jokes under socialism tend to become political and vehicles for ridiculing the regime which does not happen in non-socialist and post-socialist countries. The eminent Estonian folklorist Liisi Laineste (2009: 46) has written:

The Soviet joke tradition can also be seen as adding a general political overtone in every joke. It mocked all aspects of the absurd everyday life, turning almost every humorous text, be it situated in the bedroom, school, workplace or public space, into a political joke. The omnipresent scepticism and nihilism in Soviet jokes made a point of discrediting the regime by using every walk of Soviet life as an inspiration (see also Graham 2003: 99). 
Jokes about the frustrations of everyday economic life -the kinds of jokes which in a capitalist society with independent institutions would be apolitical and spread over many diverse targets such as the store-keeper, Macdonald's fast-food outlets, the bank-manager, the second-hand car salesman, the striking train-driver, the landlord- became under socialism political jokes. Because the state owned everything and claimed omniscience in planning, jokes about shortages and muddle were political jokes ridiculing the regime; jokes that sprung from common experience and did not require arcane political knowledge.

A Polish worker went into a department store in Warsaw.

'Do you sell spare parts for Soviet vacuum cleaners?' he asked the assistant.

'Certainly, comrade,' the assistant replied, producing a broom from behind the counter (Lukes \& Galnoor 1985: 152)

Jokes about science or the arts told in a bourgeois society are not linked to politics and may well involve specialist knowledge grafted onto a familiar structure:

We don't serve neutrinos here.

Two neutrinos walk into a bar and order drinks (oral circulation).

How do you get a viola section to play spiccato?

Write a whole note with "solo" above it (Green 2007: 54).

Political humour in a socialist society has far more scripts than in one characterised by pluralism (Raskin 1985: 222-246). In a socialist society even jokes about abstruse intellectual matters become a vehicle for political ridicule because science and the arts are constrained by the ideology of the state.

What is the leading style in Soviet Art?

Repressionism (Drozdzynski 1977: 74).

Four animals were thrown out of the zoo in Moscow.

The zebra for Formalism.

The giraffe because form took precedence over content.

The elephant for Constructivism.

The peacock for Naturalism (Drozdzynski 1977: 74).

Who invented barbed wire?

Michurin. He crossed earthworms with hedgehogs (Kolasky 1972: 111; Beckmann 1980: 67).

The distinctive feature of socialism that distinguishes it from other social and political systems is the breadth of its intrusiveness and it is this rather than the intensity of the repressiveness that has produced an unparalleled volume of popular joking that ridicules the regimes in such countries. Where everything is political and ideological then so too are the jokes. By contrast the relationship between intensity of repression and quantity of joking is not a simple linear one and there are probably more jokes in decadent times than when there is terror (Ding 2013: 238-239) but fewer when there is a prospect of major liberalisation. 


\section{Interactions}

The monist, unidirectional character of published humorous, political ridicule under socialism, despite the individual differences among authors, artists and editors, is clearly a product of its being a subset of official ridicule generally including serious ridicule without even a trace of humour and this in turn is just one part of the outpouring of exhortation and condemnation through which the Party line along with general doctrine and ideological dogma and praise of the leadership is preached. It is just one part of a much bigger pattern, characteristic of and central to a socialist society.

Regardless of how the core message is received and interpreted, incessant compulsorily preaching tends to produce a humorous response and cycles of jokes, as we can see from the rise of the disaster joke after television news broadcasts in Western countries began not only reporting but preaching about disasters (Lewis 1986) and doing so simultaneously on all the main channels. Before this there had been sick jokes but no disaster jokes (Davies 2011b) Likewise, after teaching about the Holocaust was made an important compulsory subject in Israeli schools, there was for the first time a wave of jokes that mocked and trivialised the grim details of that crime and tragedy (Zajdman 1994). There is no point in asking what such jokes mean for the participants in joke-telling or what role they have in face to face social interaction. Those who have tried to do so have resorted to a muddled blend of the unreliable, of arm-chair intuition, folk-psychology, pop psychology and Freud and come up with absurd nonsense, for example, about coping mechanisms and confused the way in which deliberate humour is directed for particular ends in particular contexts with the great mass of anonymous well-made canned jokes in circulation. All that can be additionally said about such jokes is that they are also often a response to incongruity that produces another different and constructed incongruity, thus doubling the absurdity and the humour (Oring 2003, 2011), and that they play with forbidden utterances, in this case an irreverent and distanced verbal response to tragedy. But these are qualities of most jokes including jokes about sex, misfortune, mothers in law and, of course, political jokes under socialism. Attempts have made to explain why we find incongruity and playing with the forbidden so funny (Davies 2014), but they are unprofitable and contested and do not add to our understanding. All that need to be said is that under socialism the range of forbidden utterances is far greater than in a liberal society and that socialist official statements range wider and their incongruities are more obvious. The political jokes under socialism may be usefully seen as a way of building on the humour that preaching so often produces and as a response to official socialist preaching, which includes humorous scorn and ridicule with a spontaneous ridicule that negates it produced in the form of jokes. The official published humour, the People's humour, is eagerly consumed because it has no competitors but its very lack of variety and failure to connect with everyday experience and popular discontents leads to its being supplemented and overtaken by a truly people's humour of spontaneously and anonymously created political jokes usually involving ridicule of the all-powerful established order. Such jokes are nothing like as common in bourgeois society because open criticism is permitted and there is a large supply of published ridicule of the social and political order in the form of satire, parody and mockery, whether verbal or in the form of cartoons and caricatures. There has long been a huge market for it. It was yet another consumer good not available under socialism which people had no make for themselves. 
The jokes ridicule the official ridicule. At the time when American Pershing missiles were being introduced into Western Europe to counter the proliferation of Soviet SS 20 firststrike, intermediate-range nuclear missiles, Soviet cartoonists and even official mural artists ridiculed the western statesmen who had installed them and filled their cartoons with massed rockets (Trilling 2014) but the people told jokes of a rather different kind:

An American tourist goes with a whore in Moscow. Afterwards, it is time to pay.

He puts $\$ 20$ on the table. "No", she replies.

He puts down $\$ 50$.

"No."

He puts $\$ 250$ on the table.

"No."

"But that's what I pay in Boston," says the American. Russian whore: "I don't want your dirty capitalist money. Just take your Pershings out of Europe". (Told to the author in 1984 by a friend from Moscow; for another version, see Ruksenas 1987.)

What the joke-tellers seriously thought about the Pershings, which, after all, could have taken out their own city, is irrelevant and unknowable. What we do know with certainty and what is important is that the 'evil' Pershings were being preached about.

And from China further humorous replies to the Party line:

The Shenzhou 10 rocket has been launched into space! Among the happy crowd, a reporter interviews Grandpa: "Grandpa, what do you think is the significance of this launch?" Grandpa thinks for a while and then replies, "It means that solving the problems of corruption, education, housing, health and food safety are all harder than rocket science." (Chey 2014)

Reporter: "Grandpa, what do you think of the new government's real action to stamp out corruption?"

Grandpa: "Do you mean that all those anti-corruption drives in the past were just a joke?” (Chey 2014)

\section{Conclusions}

(1) Patterns of humorous political ridicule differ markedly between socialist societies and bourgeois democracies and this is a result of the differing patterns of the exercise of power in these two contrasting types of technically advanced societies.

(2) The combination of unified, centralised power and a pervasive ideology, the very essence of socialism, leads to an unchecked cruel humour of ridicule from those with most power directed against particular individuals. The power to deploy this kind of humorous ridicule may also be delegated or permitted to activists. In a bourgeois democracy this would be seen as highly deviant behaviour by a politician or his/her supporters and would call into play constraining forces from other centres of power such as the press and public opinion, the organised opposition or the law.

(3) The published humorous ridicule in a socialist society is an attacking and admonishing official and designed humour that has perforce obedient authors and artists who are constrained to adhere to known and explicit collective purposes. The leaders and the 
ruling Party are never ridiculed whereas their real or imagined opponents or those hindering their plans are the main targets of ridicule. All publications are owned, controlled and censored by the state so that the Party has a monopoly over the means of producing humorous ridicule. In a capitalist democracy with private ownership of publications there are many diverse competing outlets for political ridicule and censorship is weaker. Those who hold political power are regularly lampooned. Power is distributed among many autonomous institutions and the links between power and ridicule, though present, are problematic. There are many centres and types of power and ridicule is spread among them.

(4) The Party's monopoly of published political ridicule in a socialist society has the unintended consequence of producing a flood of jokes spontaneously invented and circulated by ordinary people that ridicule the regime. A monopoly of official ridicule produces a countervailing unofficial ridicule. Incessant ideological preaching invites mockery. In a bourgeois society the line between the ridicule provided by professional humorists (only a few of whom work for the politicians) and that generated by the people is blurred and the professionals are often parasitic on the creations of the latter. Because professional comedians and satirists are if anything more likely to ridicule the politically powerful, those who consume their brand of ridicule have less incentive to invent their own. Jokes about politics are relatively unimportant among the citizens of a bourgeois democracy and the jokes ridicule individual politicians and policies and not the social and political order.

(5) Because the state and the Party controlled economic, cultural and scientific life far more closely and extensively under socialism than the state ever could or would seek to in a bourgeois society, all ridicule in the form of popular jokes was politicised because the entire society was politicised. Those who were in charge of everything represented themselves as benign and yet life was not and could not be anything like as rosy as they claimed. This was bound to lead to jokes at their expense, however hard the official satirists tried to blame everyday problems on low-level bureaucrats, drunken workers, foreign interference or capitalist remnants. A utopian, egalitarian ideology is anyway bound to produce a substantial and widening gap between ideal and reality in a world where the institutions shaped by the ideology can never deliver, in part because of the internal contradictions of socialism, a society without prices, where the only markets are black ones. The satirists could not use official ridicule to point this out but the unofficial jokers filled the gap. It is less the intensity of repression that leads to a proliferation of jokes that ridicule than its extensiveness. The more intrusive the exercise of power is, the more possibilities of political ridicule there are.

(6) Patterns of political ridicule may be understood without consideration of the individuals involved. They are a social fact to be understood by direct reference to another social fact (Durkheim 1950 [1894]), the nature and distribution of political power.

In the case of the cruel ridicule exercised by the most powerful members of the socialist elite or by activists unleashed by them, we can identify who in particular is handing out the mockery but this is not important in that there is in all societies a reservoir of individuals willing to behave in this way. What renders socialism different from bourgeois democracy is the concentration of power that enables people with such tastes, should they attain power, to indulge their taste for cruel mockery or to unleash it in their supporters which in a bourgeois society would be thwarted; perhaps too the distinctive channels of social mobility through party struggles are more likely to see people of this kind promoted than in a society with electoral competition and true pluralism rather than mere in-fighting by Party factions. 
Similarly, it is not the ambitions and the talents for humorous ridicule of particular writers and cartoonists that is significant but the constraints within which they must exercise them and their inability to find employment other than in an institution owned by the state and controlled by the Party. This social fact may be contrasted with that of writers and cartoonists in a capitalist democracy with many and varied potential customers and considerable less censorship and guidance from the centre.

It is the sheer number and aggregate patterns of jokes ridiculing the political order under socialism and their fewness and restricted range in a bourgeois democracy that is explicable in terms of the nature and distribution of power. As with any other analyses of joke cycles there is no need to examine the very varied ways and contexts in which individuals use jokes during a particular humorous exchange; these are not relevant to the larger picture.

\section{References}

Amis, M. (2003). Koba the Dread, Laughter and the Twenty Million. London: Vintage.

Arkhipova, A. (2009). 'Traditions and innovations in Putin jokes', in Krikmann, A. \& Laineste, L. (eds), Permitted Laughter, Tartu: ELM Scholarly Press, pp. 247-332.

Arkhipova, A. \& Alejándrez, M. (2014). "He-Who-Must-Be-Named”: Taboos and substitutions of Fidel Castro's name in Cuban folklore', in Baran, A., Laineste, L. \& Voolaid, P. (eds.), Scala Naturae: Festschrift in Honour of Arvo Krikmann, Tartu: ELM Scholarly Press, pp. 291-304.

Aulich, J. (2005). 'Boris Yefimov and the Soviet Political Cartoon', in Yefimov, B., Forced Laughter, Prague: Galerie u Křížovníků, pp.12-15.

Aulich, J. (2007). War Posters: Weapons of Mass Communication. London: Thames \& Hudson.

Ausaf (2009). 'Saudi and Egyptian humour'. Radiance 47 (19), 9 August.

Banc, C. (pseud.) \& Dundes, A. (1986). First Prize: Fifteen Years!. Cranbury, NJ: Associated University Presses.

Banc, C. (pseud.) \& Dundes, A. (1990). You Call this Living?: A Collection of East European Political Jokes. Athens, GA: University of Georgia Press.

Barry, N. (1982). 'The tradition of spontaneous order'. Literature of Liberty 5, pp. 7-58.

Beckmann, P. (1980). Hammer and Tickle: Clandestine Laughter in the Soviet Union. Boulder, CO: Golem.

Bergson, A. (1963 [1924]). Le Rire: Essai sur la Signification du Comique in Oeuvres. Paris: Presses Universitaires de la France.

Billig, M. (2005). Laughter and Ridicule. London: Sage.

British Intellectuals Visit Moscow (2014). http://www.fsmitha.com/h2/ch11-2.htm (accessed 29 October 2014).

Bronfenbrenner, U. (1974). Two Worlds of Childhood. Harmondsworth: Penguin.

Brunvand, J. H. (1973). 'Don't shoot comrades: A survey of the submerged folklore of Eastern Europe'. North Carolina Folklore Journal 21, pp. 181-188.

Bryant, M. (1989). World War II in Cartoons. London: Grub Street.

Butler, E. (2013). Foundations of a Free Society. London: IEA.

Chamberlain, W. H. (1957). "The anecdote": Unrationed Soviet humour'. Russian Review 16 (3), pp. 27-34.

Chey, J. (2014). 'More remarks from the grandpa who shocked the central government'. Personal communication; jokes from Chinese micro-blogs. 
Cochran, R. (1989). “"What courage!”: Romanian “Our Leader” jokes'. The Journal of American Folklore 142 (405), pp. 259-279.

Conquest, R. (1971). The Great Terror: Stalin's Purge of the Thirties. Harmondsworth: Penguin.

Conquest, R. (2005). The Dragons of Expectation. New York: W. W. Norton \& Company.

Courtois, S. (ed.) (1997). Le Livre Noir du Communisme: Crimes, Terreurs et Repression. Paris: R. Laffont.

Crawley, D. (2008). Posters of the Cold War. London: V \& A.

Davies, C. (1996). 'Puritanical and politically correct: A critical historical account of changes in the censorship of comedy by the BBC', in Paton, G. E. C., Powell, C. \& Wagg, S. (eds.), The Social Faces of Humour: Practices and Issues, Aldershot: Arena, pp. 29-62.

Davies, C. (1998). Jokes and their Relation to Society. Berlin: Mouton de Gruyter.

Davies, C. (2007). 'Humour and protest: Jokes under Communism'. International Review of Social History 52, pp. 291-305.

Davies, C. (2009). 'Post-socialist, socialist and never-socialist jokes and humour: Continuities and contrasts', in Krikmann, A. \& Laineste, L. (eds.), Permitted Laughter, Tartu: ELM Scholarly Press, pp. 17-38.

Davies, C. (2011a). Jokes and Targets. Bloomington, IN: Indiana University Press.

Davies, C. (2011b). 'Jokes about disasters: A response to tales told on television full of sound and fury', in Hoffstadt, C. \& Höltgen, S. (eds.), Sick Humour, Bochum: Projektverlag, pp. $11-40$.

Davies, J. (2014). Riveted. New York: Palgrave Macmillan.

Davies, S. (1997). Popular Opinion in Stalin's Russia, Terror, Propaganda and Dissent: 1934-1941. Cambridge: Cambridge University Press.

Deriabin, P. \& Gibney, F. (1960). The Secret World. London: Arthur Barker.

Dikötter, F. (2011). Mao's Great Famine: The History of China's Most Devastating Catastrophe 1958-62. London: Bloomsbury.

Ding, X.-L. (2013). 'Freedom and political humour: Their social meaning in contemporary China', in Milner-Davis, J. \& Chey, J. (eds.), Humour in Chinese Life and Culture, Hong Kong: Hong Kong University Press, pp. 231-253, 300-305.

Draitser, E. A. (1978). Forbidden Laughter: Soviet Underground Jokes. Los Angeles, CA: Almanac.

Drozdzynski, A. (1977). Der politische Witz im Ostblok. Munich: DTV.

Durkheim, E. (1950 [1894]). Les Règles de la Méthode Sociologique. Paris: Presses Universitaires de France.

Editors of Krokodil Magazine. (1989). Soviet Humour: The Best of Krokodil. London: Sedgwick \& Jackson.

Gamm, H.-J. (1979). Der Flüsterwitz im Dritten Reich. Munich: Deutscher.

García, P. (Pseud. José García Martínez-Calín) (1977). Los Chistes de Franco. Madrid: Ediciones 99.

Getty, J. A. \& Naumov. O. V. (1999). The Road to Terror: Stalin and the Self-Destruction of the Bolsheviks 1932-1939. New Haven, CT: Yale University Press.

Graham, S. B. (2003). A Cultural Analysis of the Russo-Soviet Anekdot. Pittsburgh: University of Pittsburgh $\mathrm{PhD}$ Thesis. http://etd.library.pitt.edu/ETD/available/etd11032003-192424/unrestricted/grahamsethb_etd2003.pdf

Green, J. (2007). The Musician's Joke Book. New York: Omnibus.

Halliwell, D. (1967). Little Malcolm and his Struggle against the Eunuchs. London: Faber \& Faber. 
Henderson, N. (1940). Failure of a Mission: Berlin 1937-1939. London: Hodder \& Stoughton.

Herzog, R. (2012). Dead Funny: Telling Jokes in Hitler's Germany. Brooklyn, NY: Melville.

Hillenbrand, F. K. M. (1993). Underground Humour in Nazi Germany 1933-1945. London: Routledge.

Hirche, K. (1964). Der Braune und der Rote Witz. Düsseldorf: Econ.

Hitler, A. (1973 [1953]). Hitler's Table Talk 1941-44. London: Weidenfeld \& Nicolson.

Interview with Boris Yefimov, Political Cartoonist, Pravda (1999). Abamedia. http://www.pbs.org/redfiles/prop/deep/interv/p_int_boris_efimov.htm (accessed 30 October 2014).

Isnard, A. (1977). Raconte Popov! Les Histoires Drôles de derrière le Rideau de Fer. Paris: Éditions Mengès.

Judd, D. (1972). Posters of World War Two. London: Wayland.

Kolasky, J. (1972). "Look Comrade - the People are Laughing": Underground Wit, Satire and Humor from behind the Iron Curtain. Toronto: Peter Martin.

Kosintsev, A. (2009). 'Stalin jokes and humour theory'. Russian Journal of Communication 2 (3/4), pp. 199-214.

Kovály H. M. (1986). Under a Cruel Star: A Life in Prague 1941-1968. Cambridge, MA: Plunkett Lake Press.

Kozin, A. (2009). 'Krokodil in transition: The case of the bureaucrat cartoons'. Russian Journal of Communication 2 (3/4), pp. 215-233.

Krikmann, A. (2004). Netinalju Stalinist. Tartu: Eesti Kirjandusmuuseum.

Krikmann, A. \& Laineste, L. (eds.) (2009). Permitted Laughter. Tartu: ELM Scholarly Press.

Lafont, M. (2007). Soviet Posters. Munich: Prestel.

Laineste, L. (2009). 'Political jokes in post socialist Estonia (2000-2007)', in Krikmann, A. \& Laineste, L. (eds.), Permitted Laughter, Tartu: ELM Scholarly Press, pp. 41-72.

Lamonaca, M. \& Schleuning, S. (2004). Weapons of Mass Dissemination: The Propaganda of War. Miami Beach, FL: Wolfsonian-Florida International University.

Larsen, E. (1980). Wit as Weapon: The Political Joke in History. London: Frederick Muller.

Lauchlan, I. (2010). 'Laughter in the dark: Humour under Stalin', in Chamayou, A. \& Duncan, A. (eds.), Le Rire Européen/European Laughter, Perpignan: Presses Universitaires de Perpignan, pp. 257-274.

Lewis, B. (2008). Hammer and Tickle: The History of Communism Told through Communist Jokes. London: Weidenfeld \& Nicolson.

Lewis, P. (1986). 'Disaster jokes as a laughing matter'. Chicago Tribune, 25 March, p. 19.

Li, Z. (2003). Red-Color News Soldier. London: Phaidon. For photographs see

https://uk.images.search.yahoo.com/search/images;_ylt=A2KLj9GNJ1FUxwgAUnRNBQx.; ylu=X3oDMTBsZ29xY3ZzBHNlYwNzZWFyY2gEc2xrA2J1dHRvbg-;_ylc=X1MDMjExNDcxNzAwNQRfcgMyBGJjawM0YWJkcDdwYTRwcmg2JTI2YiUz RDQIMjZkJTNELmhfNGFNQnBZRUx6WU15RjdMV3Y1ME4xc2VQczJHcHBjdEEtJTI 2cyUzRGU5JTI2aSUzRHhKXzh1X25pV2ozZ0NZUHVUdC42BGZyA31mcC10LTMwN C1zBGdwcmlkA1NJS2poWDJXVDZHbG83M0hCYnZnT0EEbXRlc3RpZANudWxsBG 5fc3VnZwMxMARvcmlnaW4DdWsuaW1hZ2VzLnNlYXJjaC55YWhvby5jb20EcG9zAz AEcHFzdHIDBHBxc3RybAMEcXN0cmwDMTIEcXVlcnkDWmhlbnNoYW5nIExpBHR fc3RtcAMxNDE0NjA0Njk4BHZ0ZXN0aWQDbnVsbA-?gprid=SIKjhX2WT6Glo73HBbvgOA\&pvid=cqhDojcyLjNFLbk.VEzuJg5HODEuMQA AAABRzPTG\&p=Zhenshang+Li\&fr=yfp-t-304-s\&fr2=sb-top- 
uk.images. search.yahoo.com\&ei $=U T F-8 \& n=60 \& x=$ wrt $\& y=$ Search $($ accessed 29 October 2014).

Lifton, R. J. (1967). Thought Reform and the Psychology of Totalism. Harmondsworth: Penguin.

Lifton, R. J. (1970). Revolutionary Immortality: Mao Tse-tung and the Chinese Cultural Revolution. Harmondsworth: Penguin.

Low, D. \& Martin, K. (1932). Low's Russian Sketchbook. London: Victor Gollancz.

Lukes, S. \& Itzhak Galnoor, I. (1985). No Laughing Matter: A Collection of Political Jokes. London: Routledge \& Kegan Paul.

Magnolia Box by Austrian Photographer. (n.d.). 'Jews forced to scrub streets of Vienna 1938'.

http://www.magnoliabox.com/art/188486/Jews_forced_to_scrub_streets_of_Vienna_1938; see also http://www.jewishvirtuallibrary.org/jsource/Holocaust/FloorScrub.html (accessed 3 November 2014).

McNeer, K. (2009). 'Soviet Cartoonist, Boris Efimov'. Passport Moscow. http://www.passportmagazine.ru/article/1565 (accessed 30 October 2014).

Marx, K. (1875). Critique of the Gotha Programme, Section 1. http://www.marxists.org/archive/marx/works/download/Marx_Critque_of_the_Gotha_Prog ramme.pdf

Maximoff, G. P. (1979 [1940]). The Guillotine at Work: The Leninist Counter-Revolution. Sanday: Cienfuegos.

Milner-Davis, J. (2003). Farce. New Brunswick, NJ: Transaction.

Min, A., Duo, D. \& Landsbergen, S. R. (2008). Chinese Propaganda Posters from the Collection of Michael Wolf. Köln: Taschen.

Montague, I. \& Marshall, H. (1943). Crocodile Album of Soviet Humour. London: Pilot Press.

Myagkov, A. (1976). Inside the KGB. Richmond: Foreign Affairs.

Nolly. (2012). 'Once upon a time Roosevelt, Stalin and Churchill decided to meet'. http://www.empowernetwork.com/adverts3/blog/once-upon-a-time-roosevelt-churchilland-stalin-decided-to-meet (accessed 23 December 2012).

Norris, S. M. (2013). 'The sharp weapon of Soviet laughter: Boris Efimov and visual humour'. Russian Literature 74 (1/2), pp. 31-62.

Oring, E. (2003). Engaging Humor. Urbana, IL: University of Illinois Press.

Oring, E. (2004). 'Risky business: Political jokes under repressive regimes'. Western Folklore 63 (3), pp. 209-236.

Oring, E. (2011). 'Parsing the joke: The General Theory of Verbal Humor and appropriate incongruity. Humor: International Journal of Humor Research 24 (2), pp. 203-222.

Payne, S. G. (1987). The Franco Regime 1936-1975. London: Phoenix.

Perakh, M. (1998). Laughing under the Covers: Russian Oral Jokes. http://www.talkreason.org/Mark\%27s\%20sites/Mark\%27s\%20perakm\%20site/members.c ox.net/marperak/jokes/leaders.htm (accessed November 2014).

Petrone, K. (2000). "Life Has Become More Joyous, Comrades": Celebrations in the Time of Stalin. Bloomington, IN: Indiana University Press.

Philippe, R. (1982). Political Graphics: Art as a Weapon. Oxford: Phaidon.

Pi-Sunyer, O. (1979). 'Political humour in a dictatorial state: The case of Spain'. Ethnohistory 24 (2), pp. 179-190.

Polanyi, M. (1951). The Logic of Liberty. London: Routledge \& Kegan Paul.

Postcards from Utopia: The Art of Political Propaganda. (2009). Oxford: Bodleian Library. 
Pryce-Jones, D. (1995). The War that Never Was: The Fall of the Soviet Empire 1985-1991. London: Weidenfeld \& Nicholson

Raskin, V. (1985). Semantic Mechanisms of Humor. Dordrecht: D. Reidel.

Rayfield, D. (2004). Stalin and his Hangmen: An Authoritative Portrait of a Tyrant and those who Served him. London: Penguin.

Rose, A. (n.d.). 'When politics is a laughing matter'. Policy Review 110. http://www.amazon.com/When-Politics-Is-Laughing-Matter/dp/B0008ILHGK (accessed 23 November 2014).

Ruksenas, A. (1987). The World's Best Russian Jokes. North Ryde: Angus \& Robertson.

Sanders, J. (1982). 'The seriousness of humour, political satire in the Soviet Bloc.' East Europe-Euromonitor 11 (1), pp. 21-29.

Sanders, J. (1962). 'The tactful satirists'. East Europe 11 (2), pp. 22-27.

Schiff, M. (1969). Radio Eriwan Antwortet. Munich: Kindler.

Schoenbaum, D. (1966). Hitler's Social Revolution: Class and Status in Nazi Germany, 1933 1939. Garden City, NY: Doubleday.

Sebag Montefiore, S. (2004). Stalin: The Court of the Red Tsar. London: Phoenix.

Service, R. (2001). 'At Stalin's right hand: Review of Sergo Beria's My Father inside Stalin's Kremlin'. The Guardian, 30 June.

Shilikhina, K. (2013). 'Canned jokes in Russian public political discourse'. European Journal of Humour Research 1 (2), pp. 84-100.

Skrobocki, E. (1992). 1001 Dowcipów Sowieckich. Bialystok: Versus.

Stoppard, T. (1978). Every Good Boy Deserves Favour: A Play for Actors and Orchestra and Professional Foul; A Play for Television. London: Faber.

Shaffer, A. (1970). Sleuth. London: Samuel French.

Shapiro, J. (2001). Mao's War against Nature. Cambridge: Cambridge University Press.

Sheygal-Placzek, E. (2009). 'The world of politics in the Russian political anekdot'. Russian Journal of Communication 2 (3/4), pp. 234-249.

Shils, E. (2006). A Fragment of a Sociological Autobiography: The History of my Pursuit of a Few Ideas. New Brunswick, NJ: Transaction.

Sloan, P. (1937). Soviet Democracy. London: Victor Gollancz.

Sturman, D. (1984). 'Six leaders in search of character'. Survey 28 (3), pp. 205-220.

Talmadge, I. D. W. (1943). 'The enjoyment of laughter in Russia'. Russian Review 2 (2), pp. 45-51.

Thurston, R. W. (1991). 'Social dimensions of Stalinist rule: Humour and terror in the USSR, 1935-1941'. Journal of Social History 24, pp. 541-562.

Trevor-Roper, H. R. (1973). 'The mind of Adolf Hitler: Introduction to Hitler's Table Talk', pp. i-xxv.

Trilling, D. (2014). Kyrgyzstan's State History Museum Awaits Post-Soviet Airbrushing $11^{\text {th }}$ April. http://www.eurasianet.org/node/68262 (accessed November 2014).

Urban, G. (1971). The Miracles of Chairman Mao: A Compendium of Devotional Literature. London: Tom Stacey.

Vaksberg, A. (1994). Stalin against the Jews. New York: Knopf.

Vazsoni, B. (1998). America's 30 Years War: Who Is Winning? Washington, DC: Regnery.

Waterlow, J. (2013). 'Intimating trust: Popular humour in Stalin's 1930s'. Cultural and Social History 10 (2), pp. 211-229.

Yefimov, B. (2005). Forced Laughter. Prague: Galerie u Kř́žovníků.

Yurchak, A. (1997). 'The cynical realism of Late Socialism: Power, pretence and the anekdot'. Public Culture 9, pp. 161-188. 
Zajdman, A. (1994). Humour. Tel-Aviv: Papyrus / Tel-Aviv University Press. Zand, A. (1982). Political Jokes of Leningrad. Austin, TX: Silvergirl.

Zlobin, N. (1996). 'Humour as a political protest'. Demokratizatsiya 4 (2), pp. 223-232. 